\title{
Water Security Plan for the Sustainable Development of Water Resources of Kadamat Jalgram, Union Territory of Lakshadweep, South India
}

\section{Joji VS*}

Scientist D, Central Ground Water Board, Ministry of Water Resources, River Development and Ganga Rejuvenation, Government of India, Thiruvananthapuram, Kerala, India

*Corresponding Author: Joji VS, Scientist D, Central Ground Water Board, Ministry of Water Resources, River Development and Ganga Rejuvenation, Government of India, Thiruvananthapuram, Kerala, India.

Received: April 01,2019; Published: June 11, 2019

DOI: $10.31080 /$ ASAG.2019.03.0519

\begin{abstract}
The Water Security Plan for the Sustainable Development of Water Resources of Kadamat Jalgram, Union Territory of Lakshadweep, South India has been studied. Kadamat island is the fourth largest of the inhabited islands of the Union Territory of Lakshadweep, with an area of $3.13 \mathrm{~km} 2$, where the fragile ground water resource is occurring as lens over marine water. The hydrogeological conditions of Kadamat island is entirely different from that existing in the main land. On the basis of the hydrogeological investigations and other related studies, certain participatory water management programs are to be urgently initiated in the island for the sustainability of water resources of the study area. The aquifers of the Kadamat are organic/coral limestones and sands with depth to the water table ranges between 1.4 and $5.0 \mathrm{mbgl}$ and the ground water occurs under phreatic condition. The phreatic water is exploited by open dug wells and filter point well and depth vary from $1.4-5.0$ and 1.8 to $6.0 \mathrm{~m}$ bgl respectively. The stage of ground water development in Kadamat is $46.7 \%$ and comes under safe category of ground water development. The electrical conductivity (EC) ranges from 500 to $15,000 \mu \mathrm{S} / \mathrm{cm}$ at $25 \mathrm{oC}$. Renovation of open dug wells, filter point wells and tanks/ponds, scientific management/conjunctive use of both surface and sub-surface water, rainwater harvesting structures to be made mandatory, awareness campaign and training programmes to be organized at grass root level on water management as aspects and water budgeting at grass root level, thrust will be given to participatory water ground water management, and an integrated water security plan for the Kadamat are to be prepared and executed.

Keywords: Hydraulic Continuity; Hydrogeology; Corals; Electrical Conductivity and Sustainability
\end{abstract}

\section{Introduction}

The Kadamat island is one among the 36 Lakshadweep Islands (LD Islands) located in the Arabian Sea which is about $400 \mathrm{~km}$ from the main land (southern tip of the Indian peninsula). There are only 10 inhabited islands and these islands lie between $\mathrm{N}$ latitudes $08000^{\prime}$ and $12013^{\prime}$ and E longitudes $71^{\circ} 00^{\prime}$ and $74^{\circ} 00$ (Figure 1). Kadamat island having an areal extent of $3.13 \mathrm{~km}^{2}$ situated between Amini and Chetlat islands and located between $\mathrm{N}$ latitudes $11^{\circ} 11^{\prime} 00^{\prime \prime}$ and $11^{\circ} 15^{\prime} 30^{\prime \prime}$ and E longitudes $72^{\circ} 15^{\prime} 30^{\prime \prime}$ and $72^{\circ} 47^{\prime} 30^{\prime \prime}$. Kadamat is elongated in shape with lagoon on the western side having 550 metres width and $8 \mathrm{Kms}$ length. The Kadamat island having an altitude of 1 to $8 \mathrm{~m}$ above the mean sea level. The location map of Kadamat with other LD islands is compiled (Figure 1). The population of Kadamat is 5404 (2011 Census statistics) and among these male and female constitute 2690 and 2714 respectively. The island with a density of 1727 , and the island with density among the Lakshadweep islands. The decadal growth rate of Kadamat is $8.34 \%$ (2001 - 2011) with literacy rate of $94 \%$.

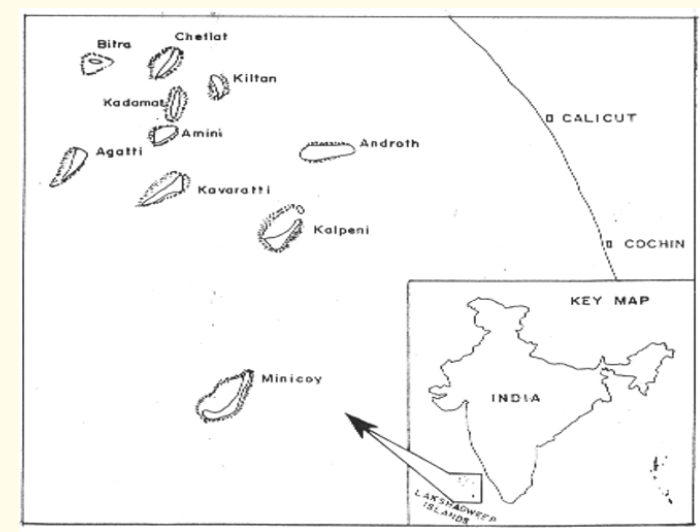

Figure 1: Location map of Kadamat including other Lakshadweep islands. 
As per the classification of coral reefs by Charles Darwin, the island of Kadamat coming under atoll with NE-SW trend. The geomorphologic units in the area are lagoon, beach, storm beaches, beach ridges, sand dunes and hinterland. The altitude ranges from 1 to 8 meters above msl with occasional sand dunes. The coral pebbles and boulders occupying the storm beach. The island is devoid of any natural drainage.

The organic coral polyps are responsible for its genesis. The purpose of the study is to propose alternate measures for Water Security Plan for the Sustainable Development of Water Resources of Kadamat Jalgram, Union Territory of Lakshadweep, South India. The sustainability development is the development of resources without sacrificing the needs of future. Its imperatives include developers must recognize the legitimacy of and give full attention to environmental concerns in their plants and projects and environmentalists must recognize the legitimacy of and full attention to economic development concerns in their efforts to protect environment. It is the environmentally sound development with minimum damage to the nature. The sustainability was one the objectives of ninth five-year plan (1992-1997). The UN Conference on Environment and Development/Agenda 21 defines the sustainable development (sustainability) as the development that needs the present without compromising the ability of future generation. The works on sustainability of water resources were carried out by many authors viz. Biswas [1], Peralta and Paralta [2], Fleming and Daniel [3], Navalawala [4], Joji and Nair [5] and many others but the small Island hydrogeological studies were carried out many authors at international and regional levels. These include Barker [6] on Freshwater - Saltwater relation, Peterson [7] groundwater recharge, storage and development on atoll Islands, Chapman [8] the use of water balances for Water Resource Estimation with Special Reference to Small Islands, Dale., et al [9]. Coral Island Hydrology, UNESCO (1991) on Hydrology and Water Resources of Small Island, Fackland [10] Review of Ground water Resources of Home and West Island, Cocos (Keeling) Islands, Najeeb [11] Groundwater resources and management in the Union Territory of Lakshadweep- Andrott and Minicoy Islands, Ajaykumar and Ramachandran [12] Resistivity survey for describing the fresh water lenses of Agatti atoll, Lakshadweep, Ajaykumar., et al. [13] groundwater resource potential in the union territory of Lakshadweep, Najeeb [14] Integrated Water Management Schemes for Lakshadweep Islands, Mondal., et al. [15] Appraisal of groundwater resources in an Island condition, Revichandran., et al. [16] Monitoring beach stability and littoral processes at Androth and Minicoy Islands, Lakshadweep. The present study is an attempt to highlight the various measures required to be adopted in the Island of Kadamat for the sustainability of the ground water resources.
Climate and soil

The island experiences tropical wet and dry (as per Koppen) with different seasons like Winter (December to February), Summer (March to May) and Monsoon (Southwest monsoon from June to September and Northeast monsoon from October to November). The Jalgram experiences average minimum and maximum temperature of $26.8^{\circ} \mathrm{C}$ and $33.1^{\circ} \mathrm{C}$ respectively. The Kadamat Island experiences normal rainfall of $1554.90 \mathrm{~mm}$ and among this $70.6 \%$ per cent of rainfall during SW monsoon, 17.8\% North-East monsoon period and $11 \%$ summer months.

The organic coral limestone has undergone weathering and resulted soil cover over organic coral limestone. The weathered products include coral sands, lagoonal sand and coral mud. As the soils of the Kadamat with high permeability and infiltration capacity, surface run off is meagre in the island but permeability and infiltration capacity decreases towards the peripherals of the Kadamat.

\section{Flora and fauna}

There are two types of flora in the area - shallow rooted (grasses, crops and shrubs) or deep rooted (coconut trees). The shallow rooted flora takes hygroscopic water from soil moisture zone coming under zone of aeration/vadose zone. The deep-rooted flora in shallow water table areas, even taking water directly from phreatic zone and behave like typical phreatophytes. The phreatophytes occur in Kadamat and other LD islands where water table is $3 \mathrm{mbgl}$. In Kadamat island coconut palms are even absorbing ground water 5 mbgl. The coconut palms are the main cultivated crop in the island. The islanders rear cattle especially goat (Capra aegagrus hircus) and poultry.

\section{Materials and Methods}

The base map of the island has been prepared by using The Survey of India Topographical Maps (Scale 1:50,000 of 1967-1968. The scanned map was digitized and edited using various Map Info 6.5 tools. Projection and polygonization of units followed the editing. During editing the segment checking like intersection, self-overlap and dead-end corrections were carried out. After polygonization, annotations were given for different polygons and the maps were subjected for further analysis. The various data pertaining to depth to the water table, quality aspects, hydrogeological scenario and related data collected during the microlevel hydrogeological survey in the Kadamat island.

\section{Results and Discussion}

The hydrogeology of the of the Island, dynamic Ground Water Resources, quality of ground water, demand for water, present status of ground water development, measures required to be 
adopted for the sustainability of ground water in the Kadamat island are briefly discussed.

\section{Hydrogeology of the of the Island}

The Kadamat island constitutes organic reefs and their weathered products encircling a lagoon. The hard-organic limestones are seen during ebb tides and at well sections. The geological succession of Kadamat is compiled (Table 1). The organic/coral limestones and sands are the aquifers in Kadamat with depth to the water table between 2 and $3 \mathrm{mbgl}$ and ground water in the Island under phreatic condition. The ground water having the shape of a thin les floating over marine water (Figure 2) and the phreatic water is mainly exploited by open dug wells.

\begin{tabular}{|l|l|}
\hline Layer & Formation \\
\hline Layer 1 & Humus \\
\hline Layer 2 & Fine coral sand \\
\hline Layer 3 & $\begin{array}{l}\text { Fine conglomerate like oolitic limestone embedded } \\
\text { with calcareous shells }\end{array}$ \\
\hline Layer 4 & Sand layer \\
\hline Layer 5 & Hard organic limestones \\
\hline
\end{tabular}

Table 1: Geological succession of Kadamat.

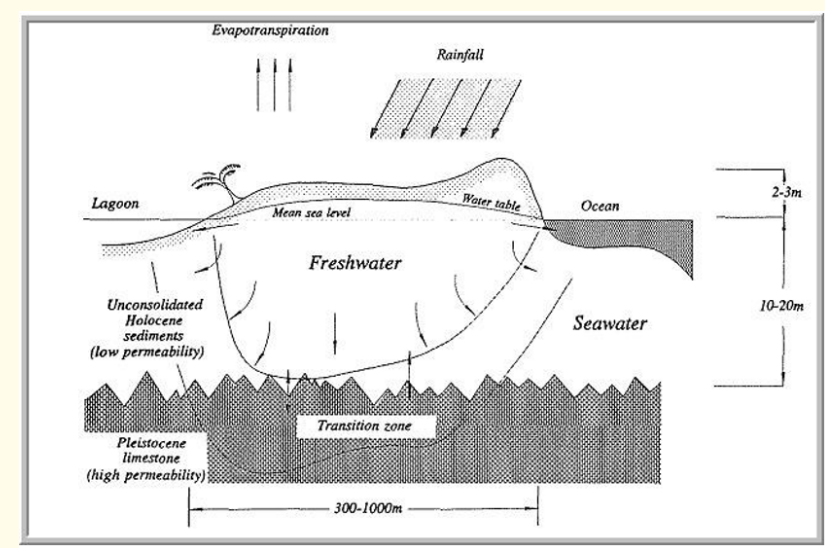

Figure 2: Freshwater lens in small Islands (Exaggerated vertical scale).

In Kadamat ground water is in hydraulic continuity with marine water, it is highly influenced by the diurnal tidal fluctuations. The magnitude of the tidal fluctuation is controlled by coefficient of permeability and proximity to sea. As the island is very elongated and having a width of $0.5 \mathrm{~km}$ only, the fresh water occurrence is under threat. The depth to the water level and depth vary from $1.4-5.0$ and 1.8 to $6.0 \mathrm{~m} \mathrm{bgl} \mathrm{respectively.}$

\section{Sources of water}

The fresh water source in Kadamat is from ground water and is extracted by dug wells with depth of water level a few meters with diameter of 1-2 m. Most of the households of Kadamat with their own wells and the water is utilised for domestic and agricultural purposes. Now a days people use mono block pumps of 0.5 HP for extracting the water.

\section{Dynamic ground water resources}

The dynamic ground water resources of Kadamat computed by considering major recharge and draft components. The rainfall is the main recharge component but draft components are domestic water consumption, evapotranspiration (consumptive use) and outflow into the sea. The $20 \%$ of the annual water surplus is reserved as buffer zone for reserve during delayed or deficit monsoon years and the details are compiled (Table 2).

\begin{tabular}{|l|l|c|}
\hline$\#$ & Annual components of Water Balance & Data \\
\hline 1 & Population (Projected as on 2017) & 5446 \\
\hline 2 & Area (Ha) & 312.0 \\
\hline 3 & Normal Monsoon Rainfall (m) & 1.355 \\
\hline 4 & Rainfall Infiltration Factor (\%) & 30 \\
\hline 5 & Total Resource (Water Surplus) (Ha.m)) [2*3*4] & 126.8 \\
\hline 6 & $\begin{array}{l}\text { ET loss from Trees for 6 non-monsoon months } \\
\text { (Ha.m) }\end{array}$ & 33.8 \\
\hline 7 & $\begin{array}{l}\text { Water loss due to outflow to sea [20\% of (3) } \\
\text { (Ha.m)] }\end{array}$ & 25.4 \\
\hline 8 & $\begin{array}{l}\text { Buffer zone for reserve during delayed or lesser } \\
\text { monsoon period [ 20\% of (3)] (Ha.m) }\end{array}$ & 25.4 \\
\hline 9 & Balance available resource (Ha.m) & 42.3 \\
\hline 10 & $\begin{array}{l}\text { Domestic Extraction @100 lpcd [1*100*365] } \\
\text { (Ha.m) }\end{array}$ & 19.8 \\
\hline 11 & Gross Annual GW Extraction (Ha.m) & 19.8 \\
\hline 12 & Groundwater balance available [9-11] (Ha.m) & 22.6 \\
\hline 13 & Stage of ground water extraction [11*100/9] & 46.7 \\
\hline 14 & Category & Safe \\
\hline
\end{tabular}

Table 2: Dynamic Ground Water Resources of Kadamat (As in March 2017).

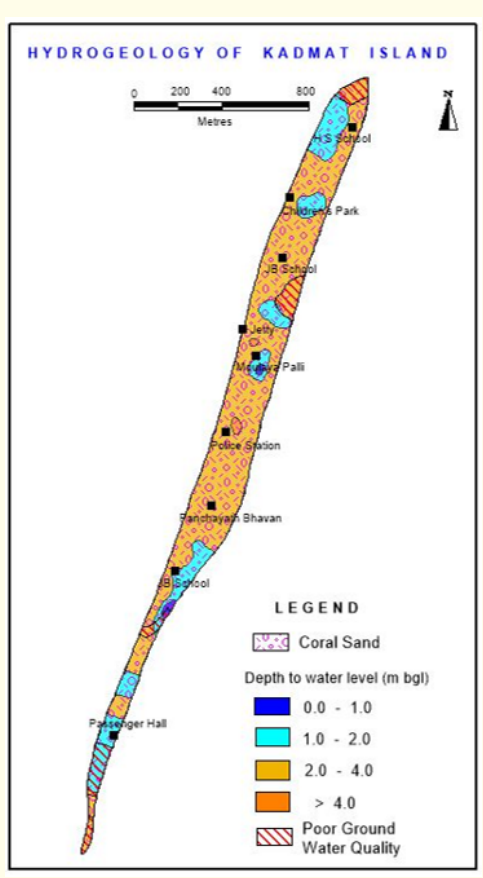

Figure 3: Hydrogeological map of the island. 


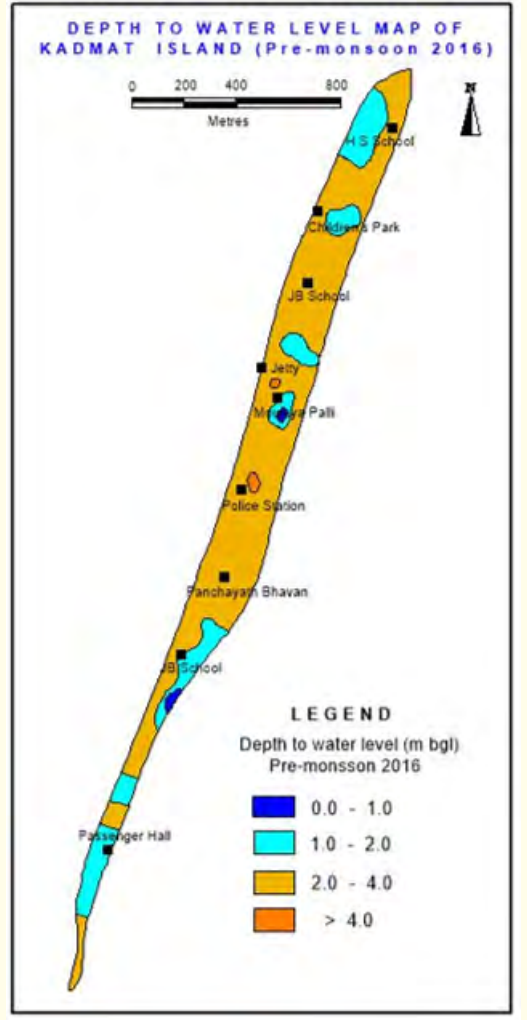

Figure 4: Depth to Water level map of the island (mbgl).

\section{Quality of ground water}

The ground water in the Kadamat is alkaline and Electrical Conductivity (EC) ranges from 500 to $15,000 \mu \mathrm{S} / \mathrm{cm}$ at $25 \mathrm{oC}$. The TDS along the periphery of the island and pumping centers is high and dilution occurs during the onset of monsoon. Besides quality is controlled by tides, recharge and discharge (draft), zone of inter face and mixing/transition zone. The quality deterioration more pronounced near mechanized wells than manually drawn and the quality deterioration is mainly expressed in the rise in EC. The quality variation is also caused by pollution from human and livestock wastes, oil spills, domestic and hotel sewerages and wastes generated by human and other organisms. The EC variation is depicted (Figure 5) and the chemical analysis data of observation wells in the island is compiled (Table 3).

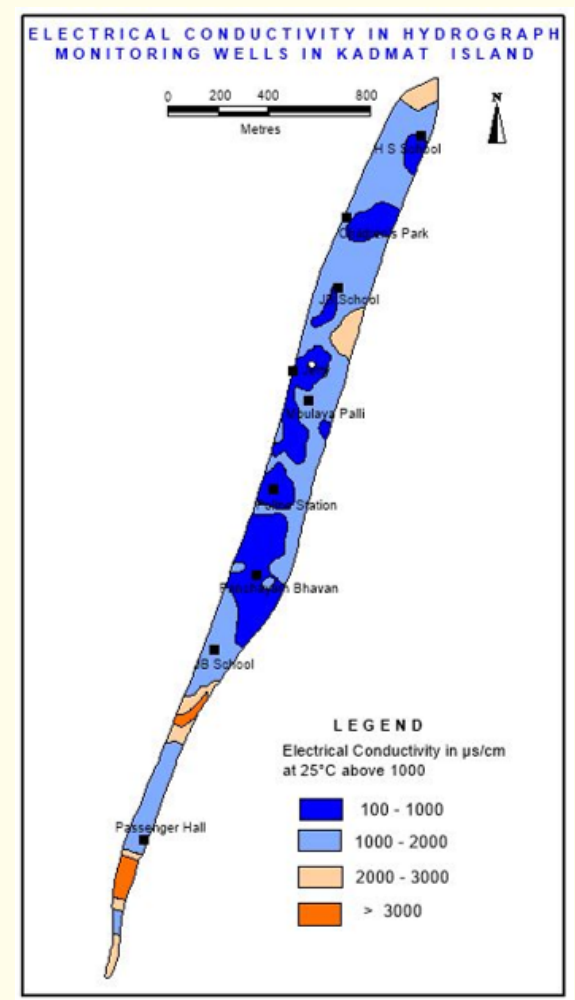

Figure 5: Distribution of Electrical conductivity in Kadamat island.

\begin{tabular}{|c|c|c|c|c|c|c|c|c|c|}
\hline \# & $\mathbf{p H}$ & $\begin{array}{c}\mathrm{EC}, \\
\mu \mathrm{S} / \mathrm{cm}\end{array}$ & $\begin{array}{c}\text { TDS } \\
(\mathrm{mg} / \mathrm{l})\end{array}$ & $\begin{array}{c}\text { Chloride, } \\
\mathrm{mg} / \mathbf{l}\end{array}$ & $\begin{array}{c}\text { TH, } \\
\mathrm{mg} / \mathrm{l}\end{array}$ & $\begin{array}{c}\text { Ca- Hardness, } \\
\mathrm{mg} / \mathrm{l}\end{array}$ & $\begin{array}{c}\text { Mg-Hardness, } \\
\mathrm{mg} / \mathrm{l}\end{array}$ & $\begin{array}{c}\text { Alkalinit } \\
\mathrm{mg} / \mathrm{l}\end{array}$ & $\begin{array}{c}\text { Salinity, } \\
\text { mg/l }\end{array}$ \\
\hline 1 & 8.05 & 7260 & 4066 & 2350 & 1250 & 200 & 1050 & 760 & 4245 \\
\hline 2 & 8.06 & 3270 & 1831 & 950 & 820 & 200 & 620 & 836 & 1716 \\
\hline 3 & 7.72 & 6200 & 3472 & 1500 & 1530 & 190 & 1340 & 840 & 2710 \\
\hline 4 & 8.1 & 11240 & 6294 & 3700 & 2100 & 200 & 1900 & 560 & 6684 \\
\hline 5 & 8.12 & 3320 & 1859 & 950 & 650 & 190 & 460 & 560 & 1716 \\
\hline 6 & 7.89 & 14940 & 8366 & 5350 & 2650 & 200 & 2450 & 792 & 9665 \\
\hline 7 & 7.79 & 6650 & 3724 & 2000 & 1510 & 190 & 1320 & 664 & 3613 \\
\hline 8 & 7.74 & 9180 & 5141 & 2500 & 2190 & 180 & 2010 & 552 & 4516 \\
\hline 9 & 7.87 & 8460 & 4738 & 2450 & 1950 & 190 & 1760 & 552 & 4426 \\
\hline 10 & 7.84 & 10110 & 5662 & 3050 & 2360 & 200 & 2160 & 792 & 5510 \\
\hline 11 & 7.84 & 2970 & 1663 & 620 & 830 & 190 & 640 & 728 & 1120 \\
\hline 12 & 7.86 & 4770 & 2671 & 1450 & 960 & 200 & 760 & 512 & 2619 \\
\hline
\end{tabular}




\begin{tabular}{|c|c|c|c|c|c|c|c|c|c|}
\hline 13 & 7.87 & 2660 & 1490 & 600 & 680 & 180 & 500 & 612 & 1084 \\
\hline 14 & 7.86 & 3490 & 1954 & 960 & 840 & 190 & 650 & 556 & 1734 \\
\hline 15 & 7.89 & 2960 & 1658 & 740 & 710 & 200 & 510 & 512 & 1337 \\
\hline 16 & 8.08 & 2990 & 1674 & 730 & 670 & 180 & 490 & 490 & 1319 \\
\hline 17 & 7.83 & 1670 & 935 & 250 & 480 & 170 & 310 & 528 & 452 \\
\hline 18 & 7.96 & 2350 & 1316 & 560 & 550 & 190 & 360 & 560 & 1012 \\
\hline 19 & 7.7 & 4460 & 2498 & 1300 & 980 & 190 & 790 & 620 & 2349 \\
\hline 20 & 7.86 & 1640 & 918 & 270 & 460 & 180 & 280 & 550 & 488 \\
\hline 21 & 8.1 & 1850 & 1036 & 310 & 600 & 180 & 420 & 400 & 560 \\
\hline 22 & 7.9 & 1460 & 818 & 190 & 400 & 130 & 270 & 400 & 343 \\
\hline 23 & 8.09 & 1500 & 840 & 210 & 400 & 170 & 230 & 364 & 379 \\
\hline 24 & 7.85 & 1760 & 986 & 220 & 450 & 170 & 280 & 416 & 397 \\
\hline 25 & 8.05 & 1370 & 767 & 150 & 500 & 180 & 320 & 412 & 271 \\
\hline 26 & 7.9 & 2110 & 1182 & 330 & 550 & 160 & 390 & 456 & 596 \\
\hline 27 & 8.05 & 1400 & 784 & 140 & 380 & 150 & 230 & 400 & 253 \\
\hline 28 & 7.76 & 1900 & 1064 & 250 & 500 & 120 & 380 & 480 & 452 \\
\hline 29 & 7.69 & 1950 & 1092 & 280 & 520 & 150 & 370 & 480 & 506 \\
\hline 30 & 7.84 & 1670 & 935 & 230 & 520 & 190 & 330 & 512 & 416 \\
\hline 31 & 8.1 & 1250 & 700 & 90 & 330 & 100 & 230 & 352 & 163 \\
\hline 32 & 8 & 1400 & 784 & 170 & 430 & 100 & 330 & 364 & 307 \\
\hline 33 & 7.97 & 1520 & 851 & 180 & 440 & 120 & 320 & 360 & 325 \\
\hline 34 & 7.99 & 1530 & 857 & 150 & 350 & 100 & 250 & 484 & 271 \\
\hline 35 & 7.8 & 1180 & 661 & 120 & 360 & 140 & 220 & 360 & 217 \\
\hline 36 & 7.74 & 1830 & 1025 & 200 & 520 & 150 & 370 & 504 & 361 \\
\hline 37 & 7.59 & 1820 & 1019 & 200 & 540 & 100 & 440 & 496 & 361 \\
\hline 38 & 7.84 & 1330 & 745 & 160 & 390 & 120 & 270 & 476 & 289 \\
\hline 39 & 7.61 & 1570 & 879 & 210 & 420 & 160 & 260 & 448 & 379 \\
\hline 40 & 8.07 & 1560 & 874 & 220 & 430 & 140 & 290 & 376 & 397 \\
\hline 41 & 7.88 & 1790 & 1002 & 250 & 530 & 170 & 360 & 400 & 452 \\
\hline 42 & 7.89 & 1390 & 778 & 100 & 390 & 150 & 240 & 460 & 181 \\
\hline 43 & 8.1 & 2120 & 1187 & 380 & 550 & 160 & 390 & 440 & 686 \\
\hline 44 & 8.08 & 1370 & 767 & 170 & 400 & 140 & 260 & 360 & 307 \\
\hline 45 & 7.92 & 1140 & 638 & 120 & 380 & 160 & 220 & 408 & 217 \\
\hline 46 & 8.09 & 1540 & 862 & 140 & 430 & 170 & 260 & 304 & 253 \\
\hline 47 & 8.09 & 1540 & 862 & 140 & 440 & 180 & 260 & 352 & 253 \\
\hline 48 & 7.93 & 1500 & 840 & 130 & 400 & 180 & 220 & 344 & 235 \\
\hline 49 & 7.85 & 2110 & 1182 & 290 & 570 & 170 & 400 & 472 & 524 \\
\hline 50 & 7.76 & 2350 & 1316 & 430 & 660 & 190 & 470 & 408 & 777 \\
\hline 51 & 7.86 & 1800 & 1008 & 250 & 560 & 160 & 400 & 420 & 452 \\
\hline 52 & 8.09 & 1350 & 756 & 140 & 400 & 140 & 260 & 364 & 253 \\
\hline 53 & 7.77 & 2190 & 1226 & 370 & 580 & 160 & 420 & 424 & 668 \\
\hline 54 & 7.9 & 1520 & 851 & 170 & 400 & 150 & 250 & 392 & 307 \\
\hline 55 & 7.68 & 1580 & 885 & 180 & 430 & 160 & 270 & 400 & 325 \\
\hline 56 & 8 & 1290 & 722 & 130 & 330 & 130 & 200 & 408 & 235 \\
\hline
\end{tabular}




\begin{tabular}{|c|c|c|c|c|c|c|c|c|c|}
\hline 57 & 8.1 & 1740 & 974 & 200 & 460 & 170 & 290 & 480 & 361 \\
\hline 58 & 8.09 & 1370 & 767 & 160 & 420 & 140 & 280 & 384 & 289 \\
\hline 59 & 8.1 & 1440 & 806 & 150 & 330 & 130 & 200 & 360 & 271 \\
\hline 60 & 8.09 & 1630 & 913 & 240 & 430 & 140 & 290 & 392 & 434 \\
\hline 61 & 8.09 & 1380 & 773 & 170 & 350 & 120 & 230 & 400 & 307 \\
\hline 62 & 7.88 & 1690 & 946 & 240 & 560 & 160 & 400 & 456 & 434 \\
\hline 63 & 8.1 & 2150 & 1204 & 380 & 580 & 150 & 430 & 500 & 686 \\
\hline 64 & 7.94 & 1350 & 756 & 140 & 450 & 130 & 320 & 472 & 253 \\
\hline 65 & 8.09 & 1320 & 739 & 130 & 330 & 140 & 190 & 480 & 235 \\
\hline 66 & 8.1 & 1300 & 728 & 150 & 380 & 100 & 280 & 432 & 271 \\
\hline 67 & 8.1 & 1340 & 750 & 150 & 390 & 150 & 240 & 420 & 271 \\
\hline 68 & 8.04 & 1420 & 795 & 130 & 470 & 140 & 330 & 352 & 235 \\
\hline 69 & 8 & 1350 & 756 & 100 & 350 & 150 & 200 & 436 & 181 \\
\hline 70 & 8.1 & 1740 & 974 & 230 & 450 & 140 & 310 & 376 & 416 \\
\hline 71 & 7.94 & 2700 & 1512 & 400 & 730 & 160 & 570 & 570 & 723 \\
\hline 72 & 8 & 1650 & 924 & 200 & 430 & 180 & 250 & 384 & 361 \\
\hline 73 & 7.86 & 1550 & 868 & 180 & 450 & 160 & 290 & 412 & 325 \\
\hline 74 & 8.07 & 1430 & 801 & 150 & 400 & 150 & 250 & 424 & 271 \\
\hline 75 & 7.93 & 1240 & 694 & 130 & 360 & 170 & 190 & 368 & 235 \\
\hline 76 & 7.75 & 2530 & 1417 & 490 & 750 & 190 & 560 & 584 & 885 \\
\hline 77 & 7.98 & 2560 & 1434 & 430 & 650 & 160 & 490 & 536 & 777 \\
\hline 78 & 7.89 & 1580 & 885 & 230 & 440 & 160 & 280 & 520 & 416 \\
\hline 79 & 7.98 & 1700 & 952 & 190 & 450 & 170 & 280 & 360 & 343 \\
\hline 80 & 8.1 & 1590 & 890 & 170 & 400 & 140 & 260 & 448 & 307 \\
\hline 81 & 7.98 & 2470 & 1383 & 420 & 650 & 180 & 470 & 520 & 759 \\
\hline 82 & 7.6 & 2920 & 1635 & 560 & 790 & 200 & 590 & 592 & 1012 \\
\hline 83 & 7.9 & 1320 & 739 & 150 & 430 & 120 & 310 & 360 & 271 \\
\hline 84 & 8.09 & 1270 & 711 & 100 & 360 & 140 & 220 & 448 & 181 \\
\hline 85 & 8.1 & 2770 & 1551 & 580 & 640 & 200 & 440 & 568 & 1048 \\
\hline 86 & 7.43 & 1260 & 706 & 140 & 370 & 140 & 230 & 440 & 253 \\
\hline 87 & 7.97 & 1280 & 717 & 170 & 390 & 130 & 260 & 400 & 307 \\
\hline 88 & 8.11 & 5290 & 2962 & 1210 & 1330 & 200 & 1130 & 660 & 2186 \\
\hline 89 & 8 & 1470 & 823 & 180 & 490 & 130 & 360 & 456 & 325 \\
\hline 90 & 8.05 & 3310 & 1854 & 780 & 810 & 190 & 620 & 540 & 1409 \\
\hline 91 & 7.9 & 1490 & 834 & 180 & 470 & 190 & 280 & 432 & 325 \\
\hline 92 & 7.93 & 2300 & 1288 & 400 & 680 & 140 & 540 & 528 & 723 \\
\hline 93 & 7.96 & 1840 & 1030 & 200 & 570 & 180 & 390 & 504 & 361 \\
\hline 94 & 7.89 & 2060 & 1154 & 350 & 500 & 180 & 320 & 464 & 632 \\
\hline 95 & 7.85 & 1860 & 1042 & 250 & 420 & 160 & 260 & 408 & 452 \\
\hline 96 & 7.99 & 1350 & 756 & 150 & 280 & 150 & 130 & 480 & 271 \\
\hline 97 & 8.05 & 1470 & 823 & 130 & 380 & 120 & 260 & 384 & 235 \\
\hline 98 & 7.7 & 1650 & 924 & 200 & 480 & 160 & 320 & 456 & 361 \\
\hline 99 & 7.9 & 1730 & 969 & 200 & 430 & 120 & 310 & 464 & 361 \\
\hline
\end{tabular}




\begin{tabular}{|l|c|c|c|c|c|c|c|c|c|}
\hline 100 & 7.88 & 1840 & 1030 & 230 & 500 & 170 & 330 & 480 & 416 \\
\hline 101 & 8.04 & 1770 & 991 & 280 & 430 & 170 & 260 & 476 & 506 \\
\hline 102 & 8.05 & 1290 & 722 & 150 & 350 & 120 & 230 & 408 & 271 \\
\hline 103 & 8.09 & 1940 & 1086 & 330 & 520 & 160 & 360 & 482 & 596 \\
\hline 104 & 7.93 & 1630 & 913 & 270 & 370 & 150 & 220 & 384 & 488 \\
\hline 105 & 7.94 & 1620 & 907 & 240 & 390 & 140 & 250 & 384 & 434 \\
\hline 106 & 7.96 & 1750 & 980 & 220 & 440 & 170 & 270 & 424 & 397 \\
\hline 107 & 8.09 & 4100 & 2296 & 1100 & 770 & 190 & 580 & 540 & 1987 \\
\hline
\end{tabular}

Table 3: Chemical analysis data of ground water in Kadamat (March 2017).

\section{Demand of water}

The people of Kadamat is mainly using the ground water for domestic purposes as there is no major industries in Kadamat except small scale industries associated with coconut. The domestic requirements are highly affected due to increasing salinity during summer and people's demand for water is met from two infiltration galleries/radial collector wells located in the island. The domestic need is further aggravated by the mechanical pumping due to mechanized pumping for construction purposes, pollution from septic tanks, sewages and waste disposal sites. As the island doesn't practice irrigated cultivation the irrigation water demand is zero and the water demand for 5404 Nos of population is computed as 20 ha $\mathrm{m}$.

\section{Present status of development}

The available resource in the island is 42.3 Ha.m and islanders use 19.8 Ha.m for domestic purposes and the balance available is 22.6 Ha.m. The stage of ground water development in Kadamat is $46.7 \%$ and coming under safe. The population in the Kadamat uses both ground water and rain water for potable purposes. There are 380 rain water harvesting storage tanks, 8 Nos of wells for public water supply and among 1061 households only 130 households are connected with public water supply schemes.

\section{Solutions}

In order to enhance the availability of water for the mankind and vegetation measures like harvesting of water and creating awareness to stakeholders on water conservation and quality aspects have to be initiated. For the sustainability of water resources of the Jalgram of Kadamat following indicatives have to be adopted.

- $\quad$ Renovation and desilting of all the water extraction structures like open dug wells, filter point wells and tanks/ ponds,

- Scientific management/conjunctive use of both surface and sub-surface water,

- Rainwater harvesting structures to be made mandatory,
- Awareness campaign and training programmes to be organized at grass root level on water management as aspects and water budgeting at grass root level,

- Thrust will be given to participatory water ground water management, and

- An integrated water security plan for the Kadamat to be prepared and executed.

\section{Conclusion}

Water Security Plan for the Sustainable Development of Water Resources of Kadamat Jalgram, Union Territory of Lakshadweep, South India has been examined in the work. The various measures urgently required for the sustainability of the meagre ground water resources of Kadamat have been proposed. These include repair, renovation and restoration of existing and abandoned water bodies like well, ponds/tanks, judicious use of ground water, construction of rainwater harvesting tanks, artificial recharge to ground water, mass awareness programs, community-based water monitoring, proper water budgeting (if possible, on a daily time step), and proper plan for water allocation for different sectors as per priority.

\section{Acknowledgements}

The author is grateful to Regional Director, Central Ground Water Board, Ministry of Water Resources, River Development and Ganga Rejuvenation, Govt. of India, Kerala Region, Thiruvananthapuram for all the encouragement given during the course of the work. Thanks, are also due to Himaganga Joji, daughter of the author for the data entry and editing of the manuscript.

\section{Bibliography}

1. Biswas Asit K. "Development and management issues: Sustainable water development: a global (1993).

2. Peralta W. et al. "Sustained Groundwater yield and conjunctive uses via target levels in a reasonable use state". Water Resources Law (1986): 235-243.

3. Fleming Nicholas S and Trevor M Daniell. "Sustainable Water Resources Management: an Australian Perspective". Water Resources Journal (1994): 17-23. 
4. Navalawala BN. "Watershed management for sustainable development”. Yojana (1998): 5 -7.

5. Joji VS and Nair ASK. "The Sustainability of Water Resources in Vamanapuram River Basin, Southern Kerala, India". Indian Journal of Geomorphology 7 (2012): 99-110.

6. Barker JA. "Freshwater - Saltwater relation' workshop on water resources of small Islands". Suva, Fuji. (1984).

7. Peterson Frank L. "Groundwater recharge, storage and development on atoll Islands. Workshop on water resources of small Islands. Suva, Fuji (1984).

8. Chapman TG "The use of Water Balances for Water Resource Estimation with Special Reference to Small Islands. Pacific Regional Team Bulletin No.4. Australian Development Assistance Bureau, Canberra. (1985).

9. Dale WR., et al. "Coral Island Hydrology. A Training Guide for Field Practice". Commonwealth Science Council Technical Publication (1986): 214.

10. Falkland AC. "Review of Ground water Resources on Home and West Island, Cocos (Keeling) Islands. ACT Electricity and Water Report No. HWR 92/1, ACT Electricity and Water, Canberra (1992).

11. Najeeb KM. "Groundwater resources and management in the Union Territory of Lakshadweep. Part II: Andrott and Minicoy Island". CGWB Report, Kerala Region (1995).

12. Ajay kumar VR and Ramachandran KK. "Resistivity survey for describing the freshwater lenses of Agatti atoll, Lakshadweep, India". Association of Exploration Geophysicists 17.1 (1996): 11-16.

13. Ajaykumar VR., et al. "Groundwater resource potential in the Union Territory of Lakshadweep, India". Indian Journal of Earth Sciences 22.4 (1995): 165-170.

14. Najeeb K Md. "Hydrogeological conditions in the Islands of UT of Lakshadweep". Unpub. Rep CGWB. (2001).

15. Mondal NC., et al. "Appraisal of groundwater resources in an Island condition". Journal of Earth System Science 118.3 (2009): 217-229.

16. Revichandran D., et al. "Monitoring beach stability and littoral processes at Androth and Minicoy Islands, Lakshadweep". Journal of Geological Survey of India. 56 (2001): 221-227.

Volume 3 Issue 7 July 2019

(C) All rights are reserved by Joji VS.

Citation: Joji VS. “Water Security Plan for the Sustainable Development of Water Resources of Kadamat Jalgram, Union Territory of Lakshadweep, South India”. Acta Scientific Agriculture 3.7 (2019): 71-78. 